\title{
Morpho-anatomical differences among mycoheterotrophic Afrothismia spp. (Thismiaceae) indicate an evolutionary progression towards improved mycorrhizal benefit
}

\author{
Stephan Imhof $^{1} \cdot$ Benjamin Feller $^{1} \cdot$ Anna Heser ${ }^{1}$
}

Received: 22 November 2019 / Accepted: 25 March 2020 / Published online: 8 May 2020

(C) The Author(s) 2020

\begin{abstract}
Achlorophyllous, mycoheterotrophic plants depend on their mycorrhizal fungi for $100 \%$ of their carbon supply. Hence, there is strong evolutionary pressure towards a well-organized functioning of the association from the plant's perspective. Members of the mycoheterotrophic genus Afrothismia have evolved elaborate fungal colonization patterns allowing a sustained benefit from external fungal penetration events. On the basis of anatomical details of the root-shoot systems of A. korupensis and A. hydra, we elucidate an evolutionary progression between the comparatively simple mycorrhizal pattern in A. gesnerioides and the so far most complex mycorrhiza in A. saingei. We detected two major advancements: (1) two species, A. korupensis and A. saingei, use the fungus itself as energy storage, replacing starch depositions used by A. gesnerioides and A. hydra, and (2) the morphological complexity of hyphal forms in plant tissue compartments increases from A. gesnerioides to A. saingei. We discuss the omitting of starch metabolism as well as the morpho-anatomical differences as an evolutionary fine-tuning of the compartmented mycorrhizal organization in Afrothismia. Our results support the idea of a taxonomic distinction between Afrothismia and other Thismiaceae.
\end{abstract}

Keywords Afrothismia $\cdot$ Mycoheterotrophy $\cdot$ Arbuscular mycorrhiza $\cdot$ Mycorrhizal benefit $\cdot$ Colonization pattern $\cdot$ Evolutionary progression

\section{Introduction}

Mycoheterotrophic plants (MHP; Leake 1994) depend on their mycorrhizal fungus not only for water and nutrients but also for $100 \%$ of their carbon supply. This essential dependency should increase the evolutionary pressure towards a wellorganized mycorrhiza in MHP. This holds in particular for MHP with limited surface of the fungi-receiving organs, resulting in reduced fungus colonization probability (the "mycoheterotroph's dilemma"; see Imhof 2010a). Indeed, most MHP have mycorrhizal colonization patterns that achieve a sustained use of the fungus by the plant even with few colonization events (e.g., Gentianaceae, Imhof 1997; Triuridaceae, Imhof 1998; Burmanniaceae, Imhof 2001). This is realized by anatomical compartmentalization: tissues

Stephan Imhof

imhof@biologie.uni-marburg.de

Spezielle Botanik, Fachbereich Biologie, Philipps-Universität, D-35032 Marburg, Germany where hyphae degrade are distinct from those in which hyphae remain intact. In addition, these tissue compartments often determine the shape of the colonizing hyphae, often indicating the service they provide, which can be conveyance, distribution, storage, and finally the digestion of fungal material.

The genus Afrothismia (Thismiaceae, after Merckx et al. 2006, 2013 and Stevens 2001 onwards; Thismieae in Burmanniaceae after APG 2009) is of African origin and includes only achlorophyllous MHP not larger than $10 \mathrm{~cm}$ in total length (Merckx et al. 2013). To date, 15 Afrothismia species have been described; $A$. winkleri comprises two varieties (Imhof 2010b onwards). All Afrothismia spp. closely aggregate their roots on rhizome-like shoots resulting in root clusters. Additional root clusters develop in the inflorescence at the pedicel bases of the monochasial cyme (see, e.g., Imhof and Sainge 2008 and Fig. 7), or on side shoots along the main axis (see Fig. 1). The morphology of a single root is remarkable, having a tuber-like base (in the following called tubercle) and a filiform extension of different lengths depending on the species. In A. gesnerioides (Maas-van de Kamer 2003), A. baerae (Cheek 2003), and A. kupensis (Cheek et al. 2019), the filiform part is very short, and only these two 
species have their root-rhizome systems subterraneous. All other Afrothismia spp. cling superficially to leaf litter, rotten wood, or the bare soil surface with their extended filiform root parts (Imhof et al. 2013). In A. saingei (Franke 2004), the rootshoot combination harbors one of the most complex mycorrhizal colonization patterns described to date. It shows four different hyphal shapes (straight, looped, inflated coils, degenerating coils) in six separate tissue compartments (filiform root, root epidermis, third root layer, root cortex parenchyma, shoot cortex at root clusters, shoot cortex apart from root clusters). Interconnections between all hyphal shapes demonstrate that they belong to the same fungus (Imhof $\left.1999 a^{1}\right)$. In contrast, the mycorrhizal pattern in A. gesnerioides is comparatively simple, with three hyphal forms in five tissue compartments (Imhof 2006; see Table 1).

The classical evidence for evolution is traits that appear in transitional series within a group of related organisms. This is most obvious in external morphology (exemplarily shown in Araceae by Engler 1884, or monocot cotyledon by Tillich 1992), but it should also hold for any trait that affects an organism's fitness. The molecular phylogeny by Merckx and Bidartondo (2008) found A. gesnerioides to be ancestral to those Afrothismia spp. with longer root extensions and epiterrestrial habit. In searching for linking structures between the considerable morpho-anatomical differences of the two mycorrhizal colonization patterns in A. gesnerioides and A. saingei, we chose Afrothismia hydra (Sainge and Franke 2005) and A. korupensis (Sainge et al. 2005), included in the phylogeny by Merckx and Bidartondo (2008), for first anatomical investigations. Moreover, morpho-anatomical details may be helpful for discussion of the familial affiliation of Afrothismia, cautiously raised by Merckx et al. (2009).

\section{Materials and methods}

During an expedition to Cameroon, following an invitation from Dr. George B. Chuyong (University of Buea, Cameroon), and under the guidance of Vincent Merckx (Leiden, The Netherlands), a flowering specimen of Afrothismia hydra Sainge and Franke (Imhof and Sainge no. 188) and a few fragments of the shoot/root complex of Afrothismia korupensis Sainge and Franke presumably shortly after flowering (Imhof and Sainge s.n.) were collected from Korup National Park near Chimpanzee Camp (53'50.20" $\mathrm{N} / 8^{\circ} 51^{\prime} 25.23^{\prime \prime}$ E, c. $136 \mathrm{~m}$ above sea level) on the 9 th of September 2006, fixed in FPA (37\% formalin:propionic acid:50\% ethanol at a ratio of 0.5:0.5:9). After 2 weeks of fixation, the specimens were transferred into $70 \%$ ethanol for

\footnotetext{
${ }^{1}$ The specimen (Wilks 1179) investigated in Imhof (1999a), labeled as Afrothismia winkleri, turned out to be a new species, later described by Franke (2004) as Afrothismia saingei (Maas-van de Kamer and Maas 2010).
}

permanent storage at the Philipps-University Marburg. The specimens of Afrothismia saingei (Wilks 1179) and Afrothismia gesnerioides (de Winter 91), kept in spirits and likewise considered in this investigation, also were collected in flowering stage, in January 1986 and April 1996, respectively. Due to the value of the material, only limited specimens could be analyzed and, hence, some variation could have been missed in this study. However, because four different Afrothismia spp. from different locations and collecting dates have been considered, which all show the same gross type of colonization pattern, and because the detailed differences between the species are quite specific, inadvertently missed variation should not affect our general conclusion.

The specimens were investigated for their external morphology, photographed with a Moticam 2300 digital camera device (Motic) mounted on a Leica S6D stereo microscope (Leica Instruments), and then prepared for anatomical studies. After dehydration in an ascending ethanol series, roots and root/shoot system were embedded in Unicryl ${ }^{\mathrm{TM}}$ (British Biocell Int.). Serial sections of 3-4 $\mu \mathrm{m}$ were made (Leica 2065 Supercut, glass knives prepared by LKB 2078 Histo Knifemaker, LKB Produkter AB, Research Instruments), stained with toluidine blue $(1 \mathrm{~g}$ toluidine blue $\mathrm{O}+1 \mathrm{~g}$ sodium tetraborate in $100 \mathrm{~mL}$ distilled $\mathrm{H}_{2} \mathrm{O}$, after Harris in Krause 1927), and mounted in Corbit-Balsam. Histological tests were performed on paraffin-embedded material (Merck, melting point $56-58^{\circ} \mathrm{C}$ ) sectioned with a Leitz 1512 hand microtome (Leitz) and deparaffinated with xylol. Suberin was tested using the Oil Red O supersaturated isopropanol technique diluted to $60 \%$ with distilled water after Lillie (1944), starch was visualized with the iodine test, and lignin was detected by phloroglucine/HCl (Jensen 1962).

Figs. 1-6 Afrothismia korupensis. 1 - Fragment of Afrothismia korupensis, showing shoot (s), and roots aggregated at side shoots (not visible). $\mathbf{f}=$ filiform root part, $\mathbf{t}=$ root tubercle. Scale bar $=5 \mathrm{~mm} .2-$ Confocal laserscan micrograph of a root tubercle, showing looped thicker hyphae (lh) in the third root layer and a straight hyphae (sh) in the epidermis. Scale bar $=100 \mu \mathrm{m} .3-$ Cross section of a shoot with longitudinal sections of two attached tubercles. The root epidermis (e) contains straight hyphae $(\mathbf{s h})$, the third tubercle layer $\left(3^{\text {rd }}\right)$ hosts hyphal coils with looped thicker hyphae (partly seen in cross section) and finely branched thinner hyphae, the inner tubercle cortex (itc) shows degenerated hyphal clumps (dh). The shoot cortex (sc) contains straight (sh, seen in cross section) as well as coiled and inflated hyphae (encircled). Note the transition of a hypha from shoot cortex to third tubercle layer (arrow) where the hypodermis is not collapsed (dotted line). $\mathbf{v c}=$ cascular cylinder, $\mathbf{h}=$ collapsed hypodermis, $\mathbf{c o}=$ calcium oxalate. Scale bar $=100 \mu \mathrm{m} .4-$ Root hypodermis $(\mathbf{h})$ with collapsed radial cell wall. $\mathbf{e}=$ epidermis, $\mathbf{3}^{\text {rd }}=$ third tubercle layer, $\mathbf{l h}=$ looped thick hypha. Scale bar $=10 \mu \mathrm{m} . \mathbf{5}-$ Cross section of the filiform root part with a minute central cylinder (cc), straight hyphae (sh, seen in cross section) and small vesicles (v). Scale bar $=50 \mu \mathrm{m}$. $\mathbf{6}$ - Inflated hyphae (ih) and straight hyphae (sh) in the shoot cortex, separated by collapsed hypodermis (h) from the $3^{\text {rd }}$ tubercle layer with densely coiled thin hyphae and looped thicker hyphae (Ih), one of which passes between cells (arrow). Rarely vesicles (v) occur in the third tubercle layer. Scale bar $=50 \mu \mathrm{m}$ 

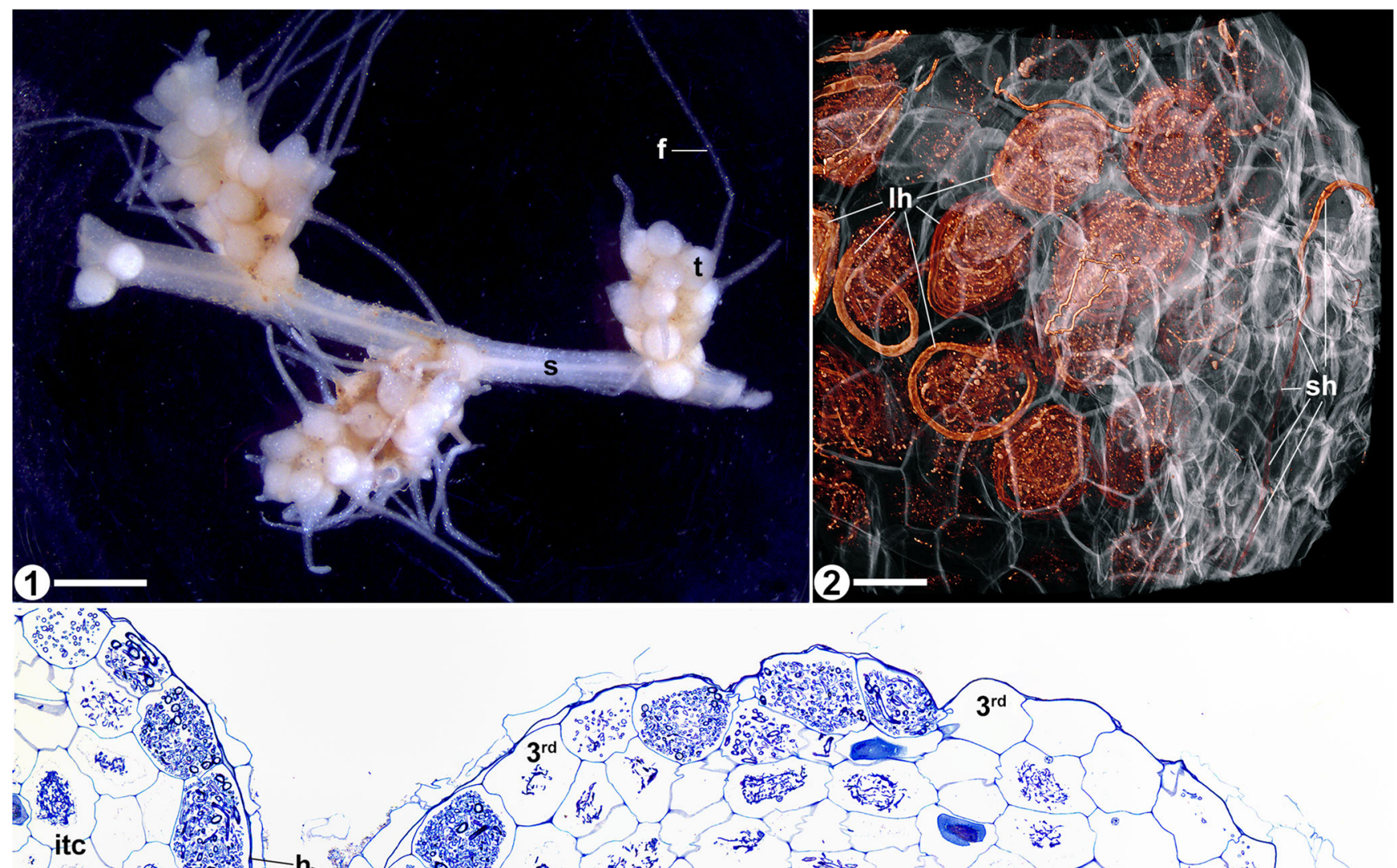

2.

(1)

(5)
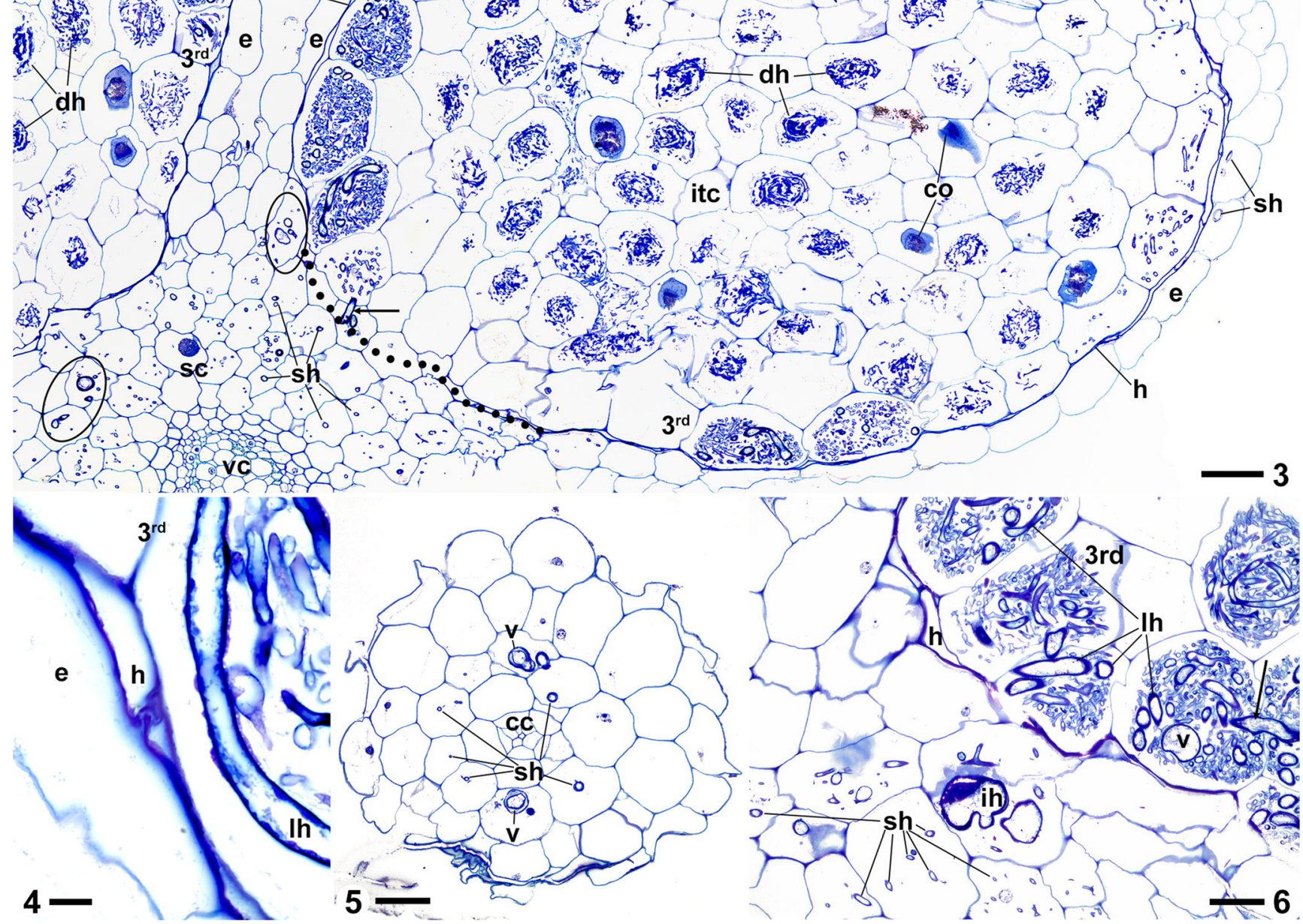
Anatomical investigations were performed using a Leitz DMRB-Microscope (Leica Instruments), equipped with a Moticam 2300 digital camera.

Samples for confocal laser scanning microscopy (CLSM) were prepared after the protocol explained in Rath et al. (2014), using Calcofluor White M2R (a non-specific stain that enhances autofluorescence) and WGA (wheat germ agglutinine) conjugated with Alexa Fluor® 633 (fungus specific) as fluorochromes. With a Leica TCX SP5 confocal laser scanning microscope (Leica Instruments), the samples were excited using an UV-Laser (405 nm, for Calcofluor) and a HeNe laser (633 nm, for Alexa Fluor $®)$. The resulting image stacks were analyzed and visualized with AMIRA ${ }^{\circledR}\left(\right.$ FEI ${ }^{\circledR}$ Visualization Sciences Group, Düsseldorf) and Leica Confocal Software (LCS, Leica Microsystems).

\section{Results}

The anatomy of roots and shoots in Afrothismia hydra and A. korupensis is similar. The rhizome-like shoots (Figs. 1, 7, and 8), measuring $1.5-2.5 \mathrm{~mm}$ in cross section, comprise a pith of parenchymatic cells, surrounded by vascular strands of weekly lignified xylem elements. Phloem elements are not obvious, if present at all. The cortex consists of an endodermis with thicker cell walls than those of the parenchyma (less pronounced in A. korupensis) and several uniform layers of cortex parenchyma (Fig. 3). The epidermis is not anatomically distinct except for its cells being slightly smaller. Shoot segments without roots bear slight longitudinal ridges.

The root tubercles of Afrothismia hydra (Fig. 7) are 1.31.6-mm long and 0.9-1.1-mm wide, and the filiform part can be up to 5 -cm long and only about $0.25-\mathrm{mm}$ wide. The tubercles of A. korupensis (Fig. 1) tend to be slightly bigger (1.31.8-mm long, up to $1.2-\mathrm{mm}$ wide), but the filiform part measured only up to $12 \mathrm{~mm}$ in length $(0.25-\mathrm{mm}$ wide). The entire root has a tender strand of vascular tissue with only one or two xylem vessels (Figs. 5 and 11). An endodermis could not be detected. In the filiform part, the vascular tissue is surrounded by few layers of parenchymatic tissue and an indistinct epidermis (Fig. 5). In contrast, the tubercle cortex comprises more cell layers and more voluminous cells around the vascular tissue and has a suberized hypodermis separating the cortex parenchyma and epidermis (Figs. 3 and 12). The hypodermis, except for young tubercles and where it merges with the shoot cortex, is largely collapsed and thus forms a doublewalled barrier between the epidermis and cortex parenchyma (Figs. 4, 6, and 10). The suberization of the hypodermal cell walls ceases at the root-shoot interface (Figs. 3 and 12, dotted lines). Calcium oxalate crystals (raphids) can occur in all parenchymatic tissues and we never saw raphids and hyphae within the same cell (Figs. 3 and 12). We found starch deposits only in the shoot cortex and the young tubercle cortex of A. hydra (Fig. 12).

The exclusively intracellular mycorrhizal fungus attains different shapes in separate tissues of Afrothismia hydra and A. korupensis. The hyphae grow in a straight manner along the axis of the root in the filiform part (Figs. 5 and 11), likewise continuing within the epidermis of the tubercle (Figs. 2, 3, and 9). They never cross the collapsed and suberized hypodermis. Vesicles can occur in the filiform part (Fig. 5).

When the straight hyphae in the tubercle epidermis reach the cortex parenchyma of the shoot, they either maintain the straight mode of growth along the shoot axis (as such interconnecting the spaced root clusters (Fig. 8), vesicles can occur) or swell irregularly and begin to coil (Fig. 3). This swelling and coiling are more pronounced in $A$. hydra (Fig. 12) than in A. korupensis (Fig. 3), but are confined in both species to the shoot cortex where roots attach. In contrast to the coils in the inner tubercle cortex (see below), these coils do not degenerate. In A. hydra, the inner shoot cortex is free of hyphae; in A. korupensis, hyphae can occur throughout the cortex (Fig. 3). Coming from the swollen coils, only one hypha enters the third root layer of the tubercle by crossing the root-shoot interface where the hypodermis has not collapsed and where suberization has ceased (Fig. 3). In the third tubercle layer, the hyphae form loops of thick hyphae in the cells, with smaller, irregularly coiled branches filling the gap in the loop (Figs. 2, 4, 9, and 12). Only thick hyphae pass between cells (Fig. 6). This hyphal mode is kept intact within this layer, gradually expanding the colonization therein towards the tubercle apex, thus encompassing the inner cortex (Fig. 9). Hyphal branches that leave the third layer into the inner cortex parenchyma coil irregularly and, in contrast to the hyphae in all other tissue compartments, degenerate (Figs. 3, 10, and 12). Arbuscules were never seen.

Figs. 7-12 Afrothismia hydra. 7 - Fragment of a cyme with shoots of two orders (s1, s2), the latter in the axil of a scale leaf (I) developing a root cluster at its base. $\mathbf{f}=$ filiform root part, $\mathbf{t}=$ root tubercle. Scale bar $=1$ $\mathrm{mm} .8$ - Confocal laserscan micrograph of a shoot without root cluster carrying straight hyphae $(\mathbf{s h})$. Scale bar $=500 \mu \mathrm{m} .9-$ Confocal laserscan micrograph of a root showing straight hyphae (sh) in the epidermis and coils with looped thicker hyphae (lh) in the third tubercle layer. $\mathbf{c o}=$ calcium oxalate. Scale bar $=500 \mu \mathrm{m} . \mathbf{1 0}-$ Longitudinal section of a root tubercle with straight hypha in the epidermis (sh). The third tubercle layer $\left(3^{\text {rd }}\right)$ contains persisting coils with looped thick hyphae, the hyphal coils in the inner cortex degenerate $(\mathbf{d h}) . \mathbf{h}=$ collapsed hypodermis. Scale bar $=100 \mu \mathrm{m} . \mathbf{1 1}$ - Confocal laserscan micrograph of a filiform root part with straight hyphae $(\mathbf{s h}) . \mathbf{c c}=$ central cylinder Scale bar $=100 \mu \mathrm{m} . \mathbf{1 2}$ - Cross section of a shoot with a root attached. The shoot cortex (sc) contains starch grains (st), coiled and inflated hyphae (ih) aside with straight hyphae (sh). The tubercle shows straight hyphae (sh) in the epidermis (e), hyphal coils with looped thicker hyphae in the third layer $\left(\mathbf{3}^{\mathbf{r d}}\right)$ and degenerating hyphal coils $(\mathbf{d h})$ in the inner tubercle cortex (itc). $c$ o $=$ calcium oxalate, dotted line $=$ root $/$ shoot interface where hyphae can cross. Scale bar $=100 \mu \mathrm{m}$ 

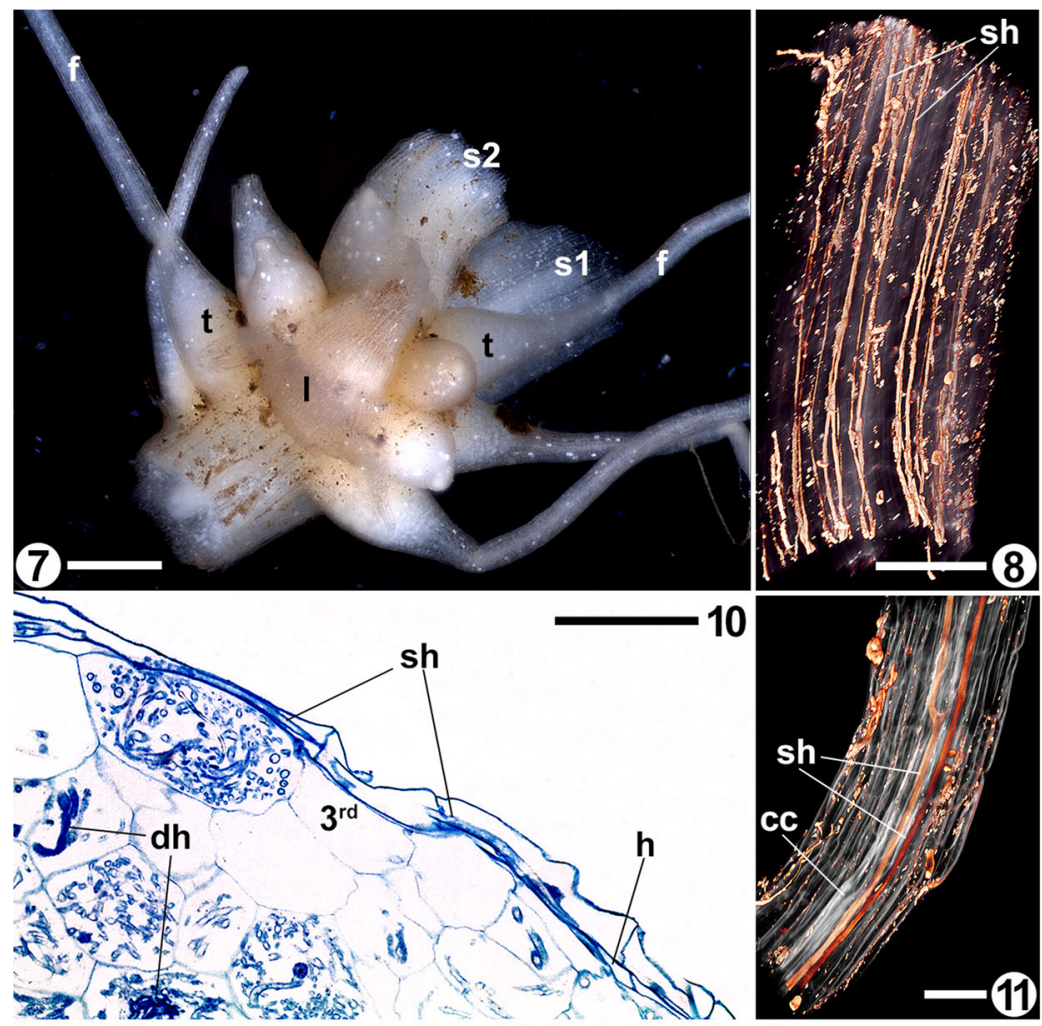

sher

(11)

1

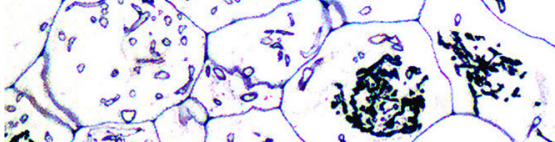

$$
\text { 年 }
$$

30.015

a

ste itc
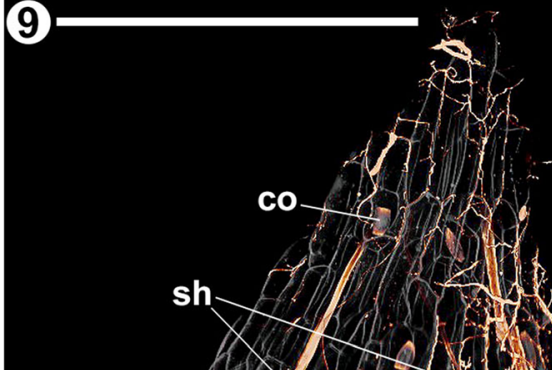

sh-

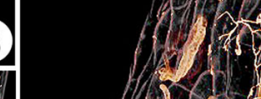

1

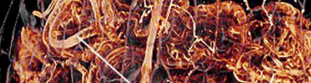

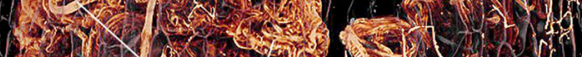

C.

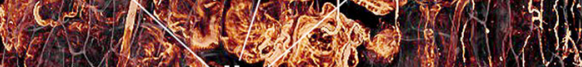

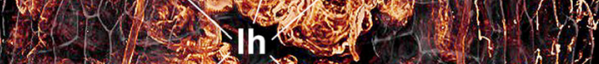

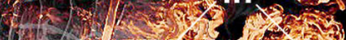

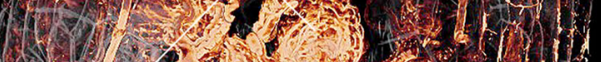

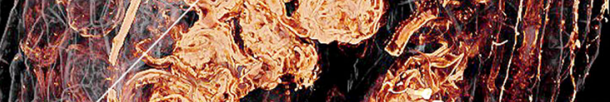

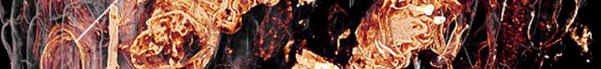

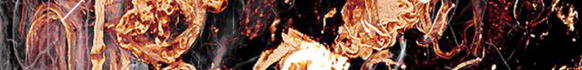

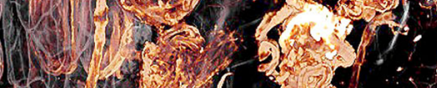

(f) $(x)=\left(j^{2}-9\right.$

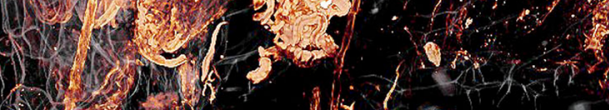

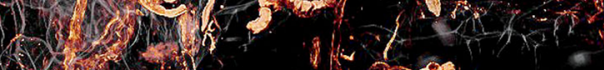

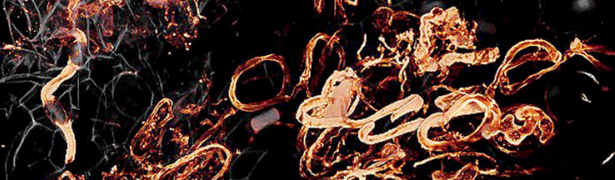

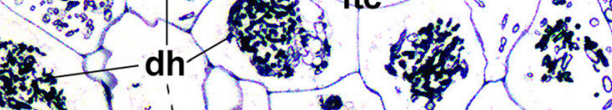

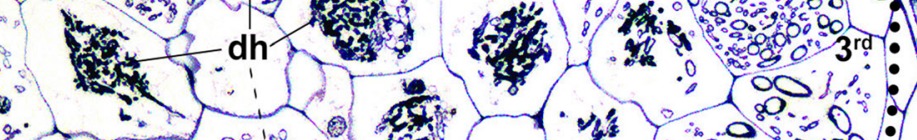

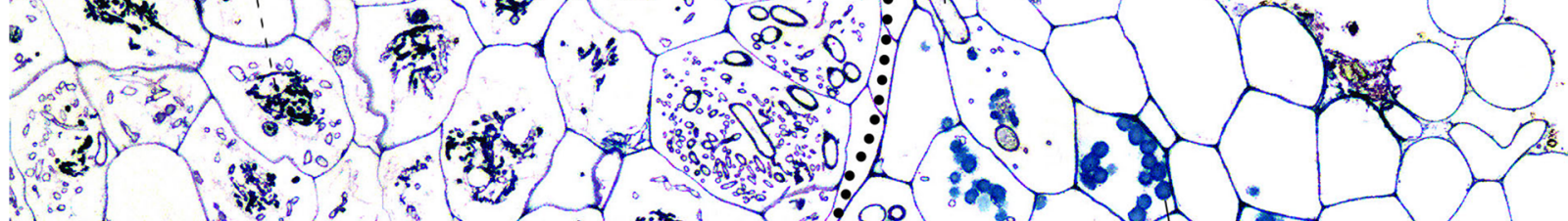
A.

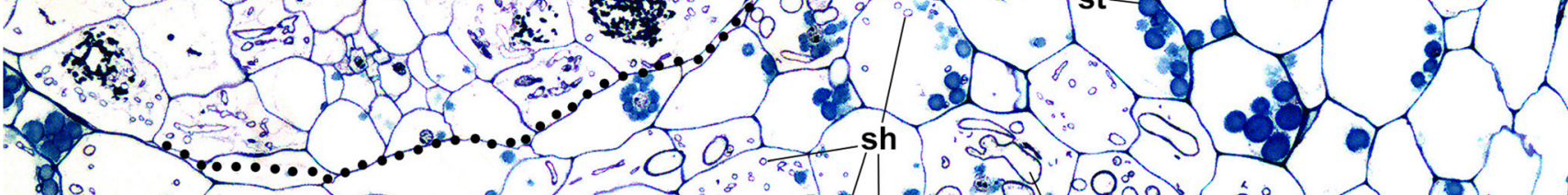
(1) 


\section{Discussion}

The morphology of root fungi in Afrothismia has been interpreted as a complex morphotype of a Paris-type arbuscular mycorrhiza (AM, Imhof 1999a, 2006); its identity as an AM fungus was later corroborated by molecular methods (Franke et al. 2006; Merckx and Bidartondo 2008; Merckx et al. 2012). Moreover, the fungi found in Afrothismia spp. belong to only one (IN A. hydra, A. korupensis, A. saingei) or to three (IN A. gesnerioides) virtual taxa from the Glomeraceae (formerly Glomus group A, Merckx et al. 2012). A. gesnerioides takes permanent advantage of penetrating mycorrhizal hyphae by hyphal forms that seem to accommodate the following demands in distinct root-shoot compartments. Straight and persistent hyphae in the short filiform root part, the tubercle epidermis, and the shoot cortex serve for long distance transport of matter. Coiled and persistent hyphae in the third tubercle layer appear to function for fine-scale distribution around the inner tubercle cortex. Finally, coiled hyphae in the inner tubercle cortex parenchyma degenerate into amorphous clumps. Because at the same time hyphae in all other tissue compartments do not degrade, this phenomenon most probably indicates the digestion of fungal matter for carbon and nutrient uptake. A mostly collapsed hypodermis separates the straight from the coiled hyphae in the epidermis and the cortex of the tubercle (details in Imhof 2006). So far, this is quite similar to the mycorrhizal patterns described here for A. hydra and A. korupensis. However, in A. gesnerioides, the inner shoot cortex and the inner tubercle cortex contain copious starch grains. Indeed, starch deposits also occur in A. hydra, albeit to a lesser extent, but starch is entirely missing in A. korupensis and A. saingei (Imhof 1999a). Converting assimilates into starch for storage is helpful for autotrophs, where assimilation is uncoupled from storage in space or time. In MHP, however, this is not the case. The carbon source, namely the fungus, is always present in the mycorrhizal tissues, and, due to the woody autotrophs in a tropical lowland forest as the ultimate carbon source for the fungus, carbon flux should be well buffered. Hence, the fungal hyphae themselves may potentially serve as storage organs, and seen from that perspective, the conversion into starch seems to be an ancestral metabolic detour. Consistent with this view, A. korupensis and A. saingei, as well as A. hydra in an intermediate stage, have omitted starch storage. Significantly, parallel to the reduction of starch deposits, these species show persistent vesicle-like hyphal coils in the rhizome, absent in A. gesnerioides, obviously appropriate to store energyrich compounds. Although this storage is located in the mycorrhizal fungus, it ultimately will be beneficial for the MHP. Because the degradation of hyphal coils, interpreted as reflecting the assimilation of carbon and mineral nutrients from the fungus, happens exclusively in the inner tubercle cortex, it appears adequate that these storage hyphae only occur in shoot segments where tubercles attach, more extensively in A. hydra than in A. korupensis. A. saingei has maximized this storage strategy: its entire rhizome-like shoot cortex at the root clusters is packed with such inflated, coiled hyphae (Imhof 1999a). We consider this transition to be a measure to reduce metabolic effort and as such to be an improvement of mycorrhizal benefit from the plant's perspective.

Straight hyphae occur in the shoot cortices as well: straight hyphae alone in A. gesnerioides (Imhof 2006), straight hyphae along with inflated coils in A. hydra and A. korupensis, and in A. saingei straight hyphae only occur in shoot segments apart from root clusters (Imhof 1999a). These straight hyphae interconnect the numerous root clusters along the entire plant up to the inflorescence and, like the inflated coils, do not degenerate. The differences in this regard between the four Afrothismia species reflect a transitional change towards more functional complexity and strict partitioning of conveyance (straight hyphae) and storage purposes (inflated hyphal coils).

Afrothismia gesnerioides has irregular coils of thin hyphae in the third tubercle layer, whereas those in A. hydra and A. korupensis are differentiated as looped thicker hyphae and irregularly coiled thinner branches. All these coils remain intact and encase the inner tubercle cortex in a collar-like manner in order to send hyphal branches into the inner cortex parenchyma, where they degenerate. Although the purpose of these loops is unknown, they do not appear to be accidental, because they also develop much more distinctly in $A$. saingei (Imhof 1999a). Furthermore, in A. saingei, they do not inhabit the complete third tubercle layer, but are restricted to a spiral line of cells around the inner tubercle cortex. Cells of the third tubercle layer that are not colonized by the looped coils contain irregular coils which degenerate (Imhof 1999a). Keeping in mind that only the inner tubercle parenchyma is able to degrade hyphal coils and, therefore, most probably is essential for the carbon input for Afrothismia spp., hyphae must reach all its cells in order for it to use its full digesting capacity. Because the hyphae-degrading forces are likely to retard hyphal growth, the hyphae should use as few cell passages as possible to reach the tubercle center. From a geometric perspective, the spiral line in A. saingei, compared with the collar-like variants in A. gesnerioides, A. hydra, and A. korupensis, is the more parsimonious option to always keep the shortest distance to the center and to any other cells of the inner tubercle parenchyma. As a result, in A. saingei, fewer cells are necessary to keep hyphae intact for this fine-scale distribution purpose, and more cells can contribute to the acquisition of carbon and nutrients through degradation of hyphae. We consider this a further advanced trait, improving the benefit from the mycorrhizal fungus by a parsimonious strategy. 
The loops of hyphae in the third root layer of three Afrothismia species are too peculiar to be ignored. In order to reduce the extent, and thus the costs, of the finescale distribution in the third tubercle layer, a cellular recognition process is mandatory for determining which coils must remain intact and which can be digested. The loops might play a role in this recognition process. While in A. gesnerioides the fungal coils are alike in all cells of the cortex, the looped coils in A. hydra and A. korupensis offer a structural means of differentiation among coils. On this basis, evolution could have selected the most parsimonious strategy of fine-scale distribution found in A. saingei. This hypothesis might also help to explain why hyphal coils within the same root layer degrade whereas others persist.

Although morphology and anatomy of the root-shoot complexes in Afrothismia species are similar, the mycorrhizal colonization patterns differ significantly. Because hyphal structures in mycorrhizas are predominantly determined by the plant (based on a prepenetration apparatus; see Genre et al. 2005,2008 ), and due to the gradual changes found (summarized in Table 1), the different colonization patterns may be viewed as an evolutionary progression within the genus to improve benefit from the fungus. From this perspective, the basal position of A. gesnerioides within its genus based on the molecular phylogenies published in Merckx and Bidartondo (2008) and Merckx et al. (2009) is reflected by the ample starch depositions, the diffuse coils, and the lack of storage hyphae. The retention of starch depositions in A. hydra therefore might suggest it to be less derived than A. korupensis which is without starch grains. On the other hand, the length of the filiform root parts and the extent of the inflated coils in the shoot cortex suggest that $A$. hydra may be the more advanced species. It is the latter view which is corroborated by molecular inferences in Merckx and Bidartondo (2008) and Merckx et al. (2009) who deem A. korupensis to be basal to A. hydra. Although A. saingei is not included in the phylogeny by Merckx and Bidartondo (2008), we suspect it to be the most advanced species for the following reasons: it has the most extensive occurrence of inflated coils in the root-bearing shoot cortex, the longest filiform root parts, and the most distinguished hyphal loops in the third layer (already visible externally; see Imhof 1999a) which in addition are organized in a spiral line of cells, and the straight hyphae in shoot cortices are restricted to those parts without root agglomerations. Another indication for the progressive character of A. saingei may be the state of the hypodermis, which probably is functionally important in all Afrothismia spp. as a barrier to prevent the fungus from entering the tubercle cortex directly. In A. korupensis and A. hydra, remnants of radial cell walls still can be found (see Figs. 4, 6, and 10), whereas in A. saingei, the hypodermis is collapsed to a degree that it became overlooked altogether in Imhof (1999a, the third tubercle layer was interpreted as the hypodermis).

A comparable mycorrhizal progression, albeit less complex, was detected in the mycoheterotrophic genus Voyria (Gentianaceae). In V. truncata, the benefit from a mycorrhizal colonization is not sustained, because penetrating hyphae become degraded right after a couple of cell passages in the root cortex (Imhof and Weber 1997). Compartmentalization of the root cortex in V. tenella enables the survival of hyphae in the inner cortex layers and allows a permanent benefit from a fungal colonization event (Imhof 1997). An intermediate colonization pattern was found in V. aphylla. By contrast with Afrothismia, the progression in Voyria is accompanied by a massive reduction of the root system: from runner-like roots up to several meters long in $V$. truncata to little star-like root clumps hardly bigger in circumference than the nail of a little finger in V. tenella (Imhof et al. 1994). V. aphylla is intermediate to this respect, also (Imhof 1999b). The familial affiliation is undisputed in the case of Voyria, which belongs to Gentianaceae since its first description by Jacquin (1763, as Gentiana aphylla). Afrothismia has been attributed to the tribe Thismieae (Miers 1847) in Burmanniaceae by its author (Engler 1905 as Thismia winkleri, transferred to Afrothismia by Schlechter 1906), but molecular characterizations by Merckx et al. (2006) revealed the monophyly of Thismieae being sister to Tacca (mostly considered to be Dioscoreaceae), whereas Burmannieae are sister to the other Dioscoreaceae, making Burmanniaceae as well as Dioscoreaceae polyphyletic. Accordingly, most recent publications see Thismiaceae (Agardh 1858), including Afrothismia, as a separate family (e.g., Lam et al. 2018; Cheek et al. 2018; Sochor et al. 2018; Chantanaorrapint and Suddee 2018; Nishioka et al. 2018; Stevens 2001 onwards). However, some inference methods calculated by Merckx et al. (2009) place Afrothismia spp. in a separate clade as sister to the pair of Tacca and the remaining Thismiaceae genera (Merckx et al. 2009) resulting in a paraphyletic Thismiaceae. Early investigations on the mycorrhizal structures of Thismia spp. describe a disparate and much less sophisticated colonization pattern (Groom 1895; Janse 1896; Meyer 1909; Pfeiffer 1914; Goebel and Süssenguth 1924; Coleman 1936; McLennan 1958; Campbell 1968) compared with those in Afrothismia spp. discussed in this paper. Hence, molecular data, classical morphological differences (listed in Merckx et al. 2009), and the distinctive mycorrhizal progression presented here argue for a deeper distinction between Thismiaceae and Afrothismia than is currently accepted. 
Table 1 Comparisons among mycorrhizal components in Afrothismia spp.

\begin{tabular}{|c|c|c|c|c|}
\hline & $\begin{array}{l}\text { Afrothismia gesnerioides } \\
\text { (after Imhof 2006) }\end{array}$ & $\begin{array}{l}\text { Afrothismia korupensis } \\
\text { (this paper) }\end{array}$ & $\begin{array}{l}\text { Afrothismia hydra } \\
\text { (this paper) }\end{array}$ & $\begin{array}{l}\text { Afrothismia saingei } \\
\text { (after Imhof 1999a) }\end{array}$ \\
\hline Rooting habit & Subterraneous & Epiterraneous & Epiterraneous & Epiterraneous \\
\hline Length of filiform root part & $\begin{array}{l}\text { Up to } 5 \mathrm{~mm} \text { (Maas-van } \\
\text { de Kamer 2003) }\end{array}$ & $\begin{array}{l}\text { Up to } 16 \mathrm{~mm} \text { (Sainge } \\
\text { et al. 2005) }\end{array}$ & $\begin{array}{l}\text { Up to } 50 \mathrm{~mm} \text { (Sainge and } \\
\text { Franke 2005) }\end{array}$ & Up to $56 \mathrm{~mm}$ (Franke 2004) \\
\hline $\begin{array}{l}\text { Hyphae in root epidermis } \\
\text { and in filiform root part }\end{array}$ & Straight, persistent & Straight, persistent & Straight, persistent & Straight, persistent \\
\hline $\begin{array}{l}\text { Hyphae in shoots between } \\
\text { the root agglomerations }\end{array}$ & $\begin{array}{l}\text { Straight and persistent in } \\
\text { outer cortex }\end{array}$ & $\begin{array}{l}\text { Straight and persistent } \\
\text { throughout the cortex } \\
\text { and longitudinal } \\
\text { ridges }\end{array}$ & $\begin{array}{l}\text { Straight and persistent in } \\
\text { outer cortex and } \\
\text { longitudinal ridges }\end{array}$ & $\begin{array}{l}\text { Straight and persistent in outer } \\
\text { cortex and longitudinal ridges }\end{array}$ \\
\hline $\begin{array}{l}\text { Hyphae in shoot cortex } \\
\text { where roots agglomerate }\end{array}$ & $\begin{array}{l}\text { Straight and persistent, in } \\
\text { outer cortex }\end{array}$ & $\begin{array}{l}\text { Straight throughout as } \\
\text { well as coiled and } \\
\text { inflated (extent: }+ \text { ) in } \\
\text { outer cortex, } \\
\text { persistent }\end{array}$ & $\begin{array}{l}\text { Straight as well as coiled and } \\
\text { inflated (extent: }++) \\
\text { persistent, in outer cortex }\end{array}$ & $\begin{array}{l}\text { Coiled and inflated (extent: }+++ \text { ), } \\
\text { persistent, throughout the } \\
\text { cortex }\end{array}$ \\
\hline $\begin{array}{l}\text { Hyphae in the third } \\
\text { tubercle layer }\end{array}$ & $\begin{array}{l}\text { Irregularly coiled, } \\
\text { persistent }\end{array}$ & $\begin{array}{l}\text { Coils with loops, } \\
\text { persistent }\end{array}$ & Coils with loops, persistent & $\begin{array}{l}\text { Persistent coils with distinct loops } \\
\text { in a spiral line around the inner } \\
\text { cortex, degrading irregular } \\
\text { coils in the other cells of the } \\
\text { third layer }\end{array}$ \\
\hline Inner tubercle cortex & Degrading irregular coils & Degrading irregular coils & Degrading irregular coils & Degrading irregular coils \\
\hline Starch deposits & $\begin{array}{l}\text { Extensively in inner shoot } \\
\text { cortex, and inner } \\
\text { tubercle cortex without } \\
\text { fungal colonization }\end{array}$ & None & $\begin{array}{l}\text { Present in outer shoot cortex, } \\
\text { and inner cortex of young } \\
\text { tubercles }\end{array}$ & None \\
\hline
\end{tabular}

Acknowledgments We are very grateful to Dr. George B. Chuyong/ University of Buea for his invitation to Cameroon as well as to Vincent Merckx/Naturalis Biodiversity Center Leiden, for giving SI the opportunity to take part in his expedition. We also thank Moses Sainge/Buea for his professional guidance during the field trip, and Magnus Rath/Marburg for sharing his experiences in confocal laser scanning microscopy with us. Many thanks as well to Merlin Sheldrake/Cambridge/UK, Friedemann Brauer/Dalhousie University/Halifax, David Janos/ University of Miami, and two anonymous reviewers for their valuable edits and comments on the first draft of the manuscript.

Funding information Open Access funding provided by Projekt DEAL.

Open Access This article is licensed under a Creative Commons Attribution 4.0 International License, which permits use, sharing, adaptation, distribution and reproduction in any medium or format, as long as you give appropriate credit to the original author(s) and the source, provide a link to the Creative Commons licence, and indicate if changes were made. The images or other third party material in this article are included in the article's Creative Commons licence, unless indicated otherwise in a credit line to the material. If material is not included in the article's Creative Commons licence and your intended use is not permitted by statutory regulation or exceeds the permitted use, you will need to obtain permission directly from the copyright holder. To view a copy of this licence, visit http://creativecommons.org/licenses/by/4.0/.

\section{References}

Agardh JG (1858) Theoria Systematis Plantarum. Gleerup, Lundae, p 99 Angiosperm Phylogeny Group (APG) (2009) An update of the angiosperm phylogeny group classification for the orders and families of flowering plants: APG III. Bot J Linn Soc 161:105-121
Campbell EO (1968) An investigation of Thismia rodwayi F. Muell. and its associated fungus. Trans Roy Soc N Z Bot 3:209-219

Chantanaorrapint S, Suddee S (2018) Thismia thaithongiana (Dioscoreaceae: Thismieae), a new species of mycoheterotroph from an unusual habitat. Phytotaxa 333(2):287-292

Cheek M (2003) A new species of Afrothismia (Burmanniaceae) from Kenya. Kew Bull 58:951-955

Cheek M, Tsukaya H, Rudall P, Suetsugu K (2018) Taxonomic monograph of Oxygyne (Thismiaceae), rare achlorophyllous mycoheterotrophs with strongly disjunct distribution. Peer J 6 . https://doi.org/10.7717/peerj.4828

Cheek M, Etuge M, Williams SA (2019) Afrothismia kupensis sp. nov. (Thismiaceae), critically endangered, with observations on its pollination and notes on the endemics of Mt Kupe, Cameroon. Blumea 64: $158-164$

Coleman D (1936) Sarcosiphon rodwayi in Australia. Vict Nat 52:163-166

Engler A (1884) Beiträge zur Kenntniss der Araceae V. 12. Über den Entwicklungsgang in der Familie der Araceen und über die Blütenmorphologie derselben. Bot Jahrb Syst 5:141-188 287-336, Taf. I-V

Engler A (1905) Thismia winkleri Engl., eine neue afrikanische Burmanniacee. Bot Jahrb Syst 38:89-91

Franke T (2004) Afrothismia saingei (Burmanniaceae, Thismieae), a new myco-heterotrophic plant from Cameroon. Syst Geogr P1 74:27-33

Franke T, Beenken L, Döring M, Kocyan A, Agerer R (2006) Arbuscular mycorrhizal fungi of the Glomus-group A lineage (Glomerales; Glomeromycota) detected in myco-heterotrophic plants from tropical Africa. Mycol Prog 5:24-31

Genre A, Chabaud M, Timmers T, Bonfante P, Barker DG (2005) Arbuscular mycorrhizal fungi elicit a novel intracellular apparatus in Medicago truncatula root epidermal cells before infection. Plant Cell 17:3489-3499

Genre A, Chabaud M, Faccio A, Barker DG, Bonfante P (2008) Prepenetration apparatus assemblys precedes and predicts the 
colonization patterns of arbuscular mycorrhizal fungi within the root cortex of both Medicago truncatula and Dacucus carota. Plant Cell 20(5):1407-1420

Goebel K, Süssenguth K (1924) Beiträge zur Kenntnis der südamerikanischen Burmanniaceen. Flora 117:55-90

Groom P (1895) On Thismia aseroe (Beccari) and its mycorhiza. Ann Bot 9:327-361

Imhof S (1997) Root anatomy and mycotrophy of the achlorophyllous Voyria tenella Hooker (Gentianaceae). Bot Acta 110:298-305

Imhof S (1998) Subterranean structures and mycotrophy of the achlorophyllous Triuris hyaline Miers (Triuridaceae). Can J Bot 76:2011-2019

Imhof S (1999a) Anatomy and mycotrophy of the achlorophyllous Afrothismia winkleri (Engl.) Schltr. (Burmanniaceae). New Phytol 144:533-540

Imhof S (1999b) Root morphology, anatomy and mycotrophy of the achlorophyllous Voyria aphylla (Jacq.) Pers. (Gentianaceae). Mycorrhiza 9:33-39

Imhof S (2001) Subterranean structures and mycotrophy of the achlorophyllous Dictyostega orobanchoides (Hook.) Miers (Burmanniaceae). Rev Biol Trop 49:239-247

Imhof S (2006) Two distinct fungi colonize roots and rhizomes of the myco-heterotrophic Afrothismia gesnerioides (Burmanniaceae). Can J Bot 84:852-861

Imhof S (2010a) Are monocots particularly suited to develop mycoheterotrophy? In: Seberg O, Petersen G, Barfod A, Davis JI (eds) Diversity, phylogeny, and evolution in the monocotyledons. Aarhus University Press, Kopenhagen, pp 11-23

Imhof S (2010b onwards) Mycoheterotrophic plants - how many of them are there? Scratchpad - biodiversity online: http://mhp.myspecies. info. Accessed 22 February 2020

Imhof S, Sainge M (2008) Ontogeny of the mycoheterotrophic species Afrothismia hydra (Burmanniaceae). Bot J Linn Soc 157:31-36

Imhof S, Weber HC (1997) Root anatomy and mycotrophy (AM) of the achlorophyllous Voyria truncata (Standley) Standley and Steyermark (Gentianaceae). Bot Acta 110:127-134

Imhof S, Weber HC, Gómez LD (1994) Ein Beitrag zur Biologie von Voyria tenella Hook. und Voyria truncata (Standley) Standley and Steyermark (Gentianaceae). Beitr. Biol. Pflanzen 68:113-123

Imhof S, Massicotte H, Melville L, Peterson R (2013) Subterranean morphology and mycorrhizal structures. In: Merckx VFST (ed) Mycoheterotrophy: the biology of plants living on fungi. Springer, Heidelberg, pp 157-214

Jacquin NJ (1763) Gentiana. Selectarum Stirpium Americanum Historia. Ex Officina Kraussiana Vindobonae, pp 87-88

Janse JM (1896) Les endophytes radicaux de quelques plantes javanaises. Ann Jard Bot Buitenzorg 14:53-212

Jensen WA (1962) Botanical Histochemistry. W. H. Freeman, San Francisco, London, pp

Krause R (1927) Enzyklopädie der Mikroskopischen Technik, 3. Aufl.. Urban und Schwarzenberg, Berlin, Wien, pp

Lam VY, Darby H, Merckx VF, Lim G, Yukawa T, Neubig K, Abbott J, Beatty G, Provan J, Gomez M, Graham S (2018) Phylogenomic inference in extremis: a case study with mycoheterotroph plastomes. Amer J Bot 105:480-494

Leake JR (1994) Tansley review no. 69. The biology of mycoheterotrophic ('saprophytic') plants. New Phytol 127:171-216
Lillie RD (1944) Various oil soluble dyes as fat stains in the supersaturated isopropanol technic. Stain Technol 19:55-58

Maas-van de Kamer H (2003) Afrothismia gesnerioides, another new species of Afrothismia (Burmanniaceae) from tropical Africa. Blumea 48:475-478

Maas-van de Kamer H, Maas PJM (2010) Thismiaceae. In: Sosef MSM (ed) Flore du Gabon. Margraf, Weikersheim, p 41

McLennan EI (1958) Thismia rodwayi F. Muell and its endophyte. Aust J Bot 6:25-37

Merckx VSFT, Bidartondo MI (2008) Breakdown and delayed cospeciation in the arbuscular mycorrhizal mutualism. Proc Roy Soc B 275:1029-1035

Merckx VSFT, Schols P, Maas-van de Kamer H, Maas P, Huysmans S, Smets E (2006) Phylogeny and evolution of Burmanniaceae (Dioscoreales) based on nuclear and mitochondrial data. Amer J Bot 93:1684-1698

Merckx VSFT, Bakker FT, Huysmans S, Smets E (2009) Bias and conflict in phylogenetic inference of myco-heterotrophic plants: a case study in Thismiaceae. Cladistics 25(1):64-77

Merckx VSFT, Jansens SB, Hynson NA, Specht CD, Bruns TD, Smets EF (2012) Mycoheterotrophic interactions are not limited to a narrow phylogenetic range of arbuscular mycorrhizal fungi. Molec Ecol 21(6):1524-1532

Merckx VSFT, Freudenstein J, Kissling J, Christenhusz MM, Stotler R, Crandall-Stotler B, Wickett NRJ, Maas-van de Kamer H, Maas PM (2013) Taxonomy and classification. In: Merckx VSFT (ed) Mycoheterotrophy: the biology of plants living on fungi. Springer, Heidelberg, pp 19-101

Meyer K (1909) Untersuchungen über Thismia clandestina. Bull Soc Imp Nat Moscou 1909:1-18

Miers J (1847) On a new genus of plants of the family of Burmanniaceae. Trans. Linn. Soc. London 20 (1): 373-381 + tab. 15

Nishioka T, Suetsugu K, Repin R, Kitayama K (2018) Thismia kinabaluensis (Thismiaceae), a new species from Mt. Kinabalu, Sabah, Borneo. Phytotaxa 360(2):174-178

Pfeiffer NE (1914) Morphology of Thismia americana. Bot Gaz 57:122-135

Rath M, Grolig F, Haueisen J, Imhof S (2014) Combining microtomy and confocal laser scanning microscopy for structural analysis of plantfungus associations. Mycorrhiza 24:293-300

Sainge M, Franke T (2005) A new species of Afrothismia (Burmanniaceae) from Cameroon. Nord J Bot 23:299-303

Sainge M, Franke T, Agerer R (2005) A new species of Afrothismia (Burmanniaceae, tribe Thismieae) from Korup National Park, Cameroon. Willdenowia 35:287-291

Schlechter R (1906) Burmanniaceae africanae. Bot Jahrb Syst 38:137-143

Sochor M, Hroneš M, Dančák M (2018) New insights into variation, evolution and taxonomy of fairy lanterns (Thismia, Thismiaceae) with four new species from Borneo. P1 Syst Evol 304(5):699-721

Stevens PF (2001 onwards) angiosperm phylogeny website. http://www. mobot.org/MOBOT/research/APweb. Accessed 22 February 2020

Tillich H-J (1992) Bauprinzipien und Evolutionslinien bei monocotylen Keimpflanzen. Bot Jahrb Syst 114:91-132

Publisher's note Springer Nature remains neutral with regard to jurisdictional claims in published maps and institutional affiliations. 